\title{
Indonesia: Islam and health
}

$\mathrm{T}$ he incongruities and subtleties are sometimes startling, but then, they typically are when the worlds of religion and medicine intersect and there's no reason to expect that Indonesia, the world's most populous Muslim nation, would be any different.

Officially, health care is provided on a secular basis in this nation of 248 million, $80 \%$ of whom are Muslim, and some clinicians insist that is actually the case.

But the interplay of faith and science is rarely straightforward. Surveys seem to suggest that the first instinct of people seeking care in this dazzling nation of 15000 islands is to seek the services of a traditional healer. Islam appears to play an extremely potent role in such matters as vaccination and reproductive health. And when it comes to many issues in the area of women's health, including such things as breastfeeding, access to abortion and genital mutilation, the nuances can be surprising.

Technically, Indonesia is secular, though many religious organizations, most notably the Islamic organizations Persyarikatan Muhammadiyah and Nahdlatul Ulama, operate health facilities. But even those facilities treat patients of all faiths, argues Dr. Untung Suseno Sutarjo, senior adviser on health financing and community empowerment to the Indonesian Ministry of Health and a family physician who believes that religion has no bearing on physician-patient relations in Indonesia.

That's definitely the case, argues Dr. Mora Claramita, professor in the Fac- ulty of Medicine at Gadjah Mada University in Yogyakarta, in eastern Java. "Islamic influences have little or no clinical impact," she insists. "In places like Iraq and Saudi Arabia, everything is dependent on Allah. Here in Asia, it is not the same."

Yet, for a typical Indonesian family seeking health care, alternative healers are almost always the first resort and the influence of Islam alongside local spiritual concepts is often overt, says Nelly van Doorn-Harder, professor of Islamic Studies at Wake Forest University in Winston Salem, North Carolina. "For the average Indonesian who is a practising Muslim, it is absolutely normal to couch health care guidance within an Islamic framework."

Traditional healers are hugely important, argues Avita Usfar, head of

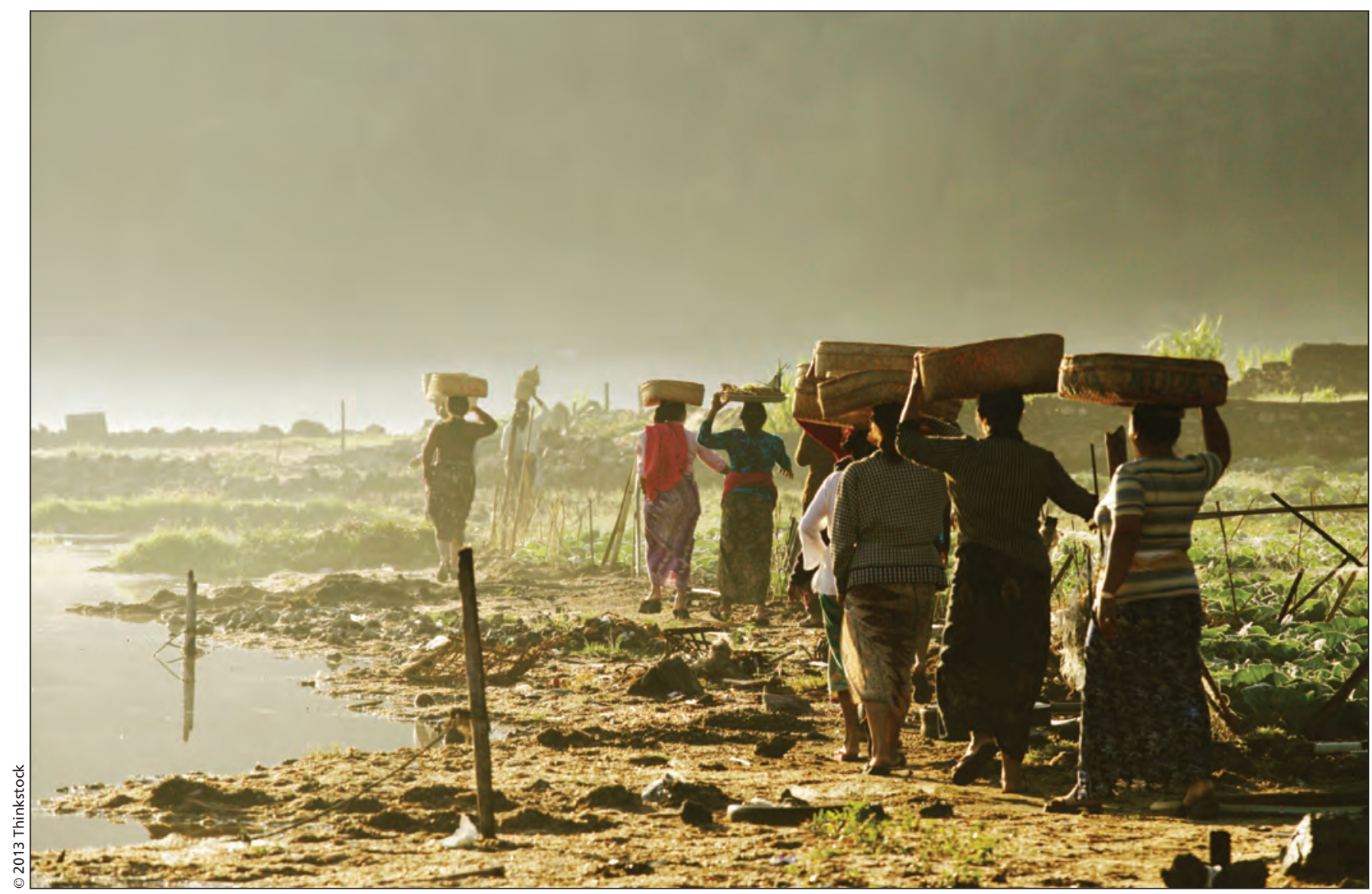

Rural areas of Indonesia often rely heavily on traditional healers to provide health care. 
the secretariat for an internal government think tank, the Indonesian National Team for the Acceleration of Poverty Reduction. Although "activities such as weight monitoring, vaccination, and distribution of nutritional supplementation are religion-free" in public health clinics, government surveys indicate that there is extensive reliance on alternative healing, she says.

The Islamic influence is no less pervasive, although several observers, such as Claudia Surjadjaja, executive director of the Jakarta-based ALERTAsia Foundation (Alliance for Emerging \& Re-emerging Infectious Threats in Asia), argues that it is often benign. On the issue of family planning and contraception, for example, the government succeeded in overturning strong clerical opposition, she notes.

That's not to say that the Islamic factor has no impact on health matters, says Dr. Aasim Padela, assistant professor of medicine and director of the Initiative on Islam and Medicine at the University of Chicago in Illinois. In the area of vaccine use, for example, a 2008 fatwa issued by the nation's top Muslim clerical body, the Indonesian Ulema Council, banned the use of a meningitis vaccine because it included an enzyme derived from pigs, notes Padela. "On the basis of this decision, the health ministry of Indonesia halted the distribution of this meningitis vaccine, which put the Hajj journey of more than 200000 Indonesian pilgrims at risk because meningitis vaccination was required in order to obtain a Hajj visa." The ministry was obliged to procure a different, much more expensive vaccine, he adds.

It is often in the area of women's health, though, where the anomalies and tensions are most evident.

Even a seemingly straightforward issue like breastfeeding can be a miasma. Only about $15 \%$ of Indonesian women breastfeed their infants, according to government estimates. The Indonesian Breastfeeding Association asserts that low tally is a function of industrial policy, (i.e., the reluctance of Indonesia's maledominated Parliament to restrict the marketing of baby formula). "Thirty years of aggressive, and mostly unethical, marketing and promotion of infant formula has eroded centuries of the general population's confidence in mom's breast milk, even in a predominantly Muslim country," Mia Sutanto, founder of the association, noted at a breastfeeding workshop in October,

To combat that, the association turned to social media such as Twitter, Facebook and Blackberry Messaging to get out their message that women should have control over a primal aspect of motherhood.

Surprisingly, it also turns to the Islamic holy book, the Koran.

"It is a very strong belief here that breastfeeding is part of the way we worship God," Nia Umar, the association's deputy chair writes in an email, while citing a Koran stipulation that mothers breastfeed for two years. "That's why a lot of mothers try to breastfeed. Eventually, though, they stop due to the unsupportive environment."
But rarely do women's health advocates so directly turn to theological text for support, notes van Doorn-Harder. The role of the Koran is often much more ambiguous, she notes, citing cleric use of the book to promote the increasingly common practice in Indonesia of female genital mutilation. "At one time the Koran was used to fight the practice. Now the fundamentalists use it to promote it officially in clinics as a package after birth. It's really circumcision."

Nowhere are the incongruities between the interplay of religion and medicine more evident, however, than with regard to the issue of abortion.

Indonesian criminal law, modelled in part on sharia law (the Islamic moral code based on the precepts of the Koran and the examples set by the Islamic prophet Muhammad), forbids abortion, Surjadjaja notes. But Indonesian legislation permits it if a woman's life is endangered and "some clinics will provide abortions in the case of contraceptive failure because it is then deemed to be a health service failure and not the fault of the woman who had taken reasonable steps to prevent unwanted pregnancy."

Essentially, "the legal status of abortion has been deliberately left gray," by two contradictory laws, Surjadjaja adds, "which reveals that religion really does play an important role in health care policy-making." - Paul Christopher Webster, Jakarta, Indonesia

CMAJ 2013. DOI:10.1503/cmaj.109-4364 